\title{
Androgenetic alopecia as a cardiovascular risk factor
}

\section{Łysienie androgenowe jako czynnik ryzyka sercowo-naczyniowego}

\author{
Aneta Wernicka', Maciej Wyzgał', Anna Waśkiel-Burnat², Mariusz Sikora² \\ 'Students' Research Association at the Department of Dermatology, Medical University of Warsaw, Poland \\ ${ }^{2}$ Department of Dermatology, Medical University of Warsaw, Poland
}

IStudenckie Koło Naukowe przy Katedrze i Klinice Dermatologicznej Warszawskiego Uniwersytetu Medycznego, Polska ${ }^{2}$ Katedra i Klinika Dermatologiczna Warszawskiego Uniwersytetu Medycznego, Polska

Dermatol Rev/Przegl Dermatol 2018, 105, 716-725 DOI: https://doi.org//0.5।|4/dr.2018.8084|

\section{CORRESPONDING AUTHOR/ ADRES DO KORESPONDENCJI:} dr n. med. Mariusz Sikora Katedra i Klinika Dermatologiczna Warszawski Uniwersytet Medyczny

ul. Koszykowa 82 A 02-008 Warszawa, Polska

tel.: +48225021324

e-mail: msikora@wum.edu.pl

\begin{abstract}
Androgenetic alopecia is the most common cause of chronic hair loss. The first reports indicating the relationship between androgenetic alopecia and cardiovascular diseases were published in the 1970s. Epidemiological studies confirmed a more frequent occurrence of ischaemic heart disease, development of atherosclerosis and an increased risk of cardiovascular death in this group of patients. Metabolic syndrome and the presence of its components: arterial hypertension, dyslipidemia, insulin resistance and visceral obesity are more frequent in androgenetic alopecia. The pathomechanism of co-occurring androgenetic alopecia and cardiovascular diseases includes several factors such as genetic (increased sensitivity to androgens and activity of $5 \alpha$-reductase), hormonal (increased concentration of insulin, aldosterone, leptin) and inflammatory (cytokines, free oxygen radicals). Androgenetic alopecia, especially when it begins before the age of 30 , has been identified as an independent cardiovascular risk factor. Women and men with pattern hair loss should be closely monitored for other risk factors to start prophylaxis.
\end{abstract}

\section{STRESZCZENIE}

Łysienie androgenowe stanowi najczęstszą przyczynę utraty włosów u kobiet i mężczyzn. W latach 70. XX wieku pojawiły się pierwsze doniesienia wskazujące na związek łysienia androgenowego z chorobami układu krążenia. Późniejsze badania epidemiologiczne potwierdziły częstsze występowanie $\mathrm{w}$ tej grupie pacjentów choroby niedokrwiennej serca, przyspieszony rozwój miażdżycy oraz większe ryzyko zgonu z przyczyn sercowo-naczyniowych. U osób z łysieniem androgenowym częściej stwierdza się zespół metaboliczny oraz obecność jego poszczególnych składowych, takich jak nadciśnienie tętnicze, dyslipidemia, insulinooporność i otyłość trzewna. Patomechanizm współwystępowania łysienia androgenowego i chorób sercowo-naczyniowych jest złożony i obejmuje czynniki genetyczne (zwiększona wrażliwość na androgeny i aktywność $5 \alpha$-reduktazy), hormonalne (zwiększone stężenie insuliny, aldosteronu, leptyny) oraz zapalne (cytokiny, wolne rodniki tlenowe). Łysienie androgenowe, zwłaszcza rozpoczynające się przed 30. rokiem życia, uznano za niezależny czynnik ryzyka sercowo-naczyniowego. Kobiety i mężczyźni z androgenową utratą włosów powinni być okresowo monitorowani w celu poszukiwania innych czynników ryzyka, aby jak najszybciej rozpocząć działania profilaktyczne. 
Key words: androgenetic alopecia, atherosclerosis, cardiovascular risk, metabolic syndrome.

Słowa kluczowe: łysienie androgenowe, miażdżyca, ryzyko sercowo-naczyniowe, zespół metaboliczny.

\section{INTRODUCTION}

Androgenetic alopecia is the most common cause of excessive hair loss in adults [1,2]. Not only does it exert a negative influence on quality of life [3], but also more and more studies suggest that androgenetic alopecia is associated with to an increased cardiovascular risk $[4,5]$. People with androgenetic alopecia are more frequently found to suffer from an accelerated development of atherosclerosis, arterial hypertension, dyslipidemia, insulin resistance, and obesity.

\section{ATHEROSCLEROSIS}

Cotton et al. mentioned the relationship between androgenetic alopecia and heart diseases for the first time in British Heart Journal in 1972 [6]. Epidemiological studies conducted in subsequent years confirmed this connection. An ongoing analysis of Framingham population (Framingham Heart Study), which started in 1948, showed a relationship between the rate of progression as well as severity of androgenetic alopecia in men and the occurrence of ischaemic heart disease as well as an increased risk of death caused by myocardial infarction [7]. Christoffersen et al. showed the results of a 35-year observation of 10,885 women and men that participated in Copenhagen City Heart Study [8]. The authors confirmed that androgenetic alopecia increases the risk of ischaemic heart disease $(1.4 \times)$ and myocardial infarction $(1.57 \times)$ regardless of sex and presence of other factors associated with cardiovascular events [8]. A meta-analysis of 31 cross-sectional studies, in which a total of 29,254 patients was evaluated, showed that androgenetic alopecia increases the risk of ischaemic heart disease $(1.22 \times)$, which also positively correlates with the severity of alopecia [9].

Furthermore, indirect evidence coming from medical imaging and laboratory tests is indicative of the relationship between androgenetic alopecia and an accelerated development of atherosclerosis. An ultrasound measurement of the thickness of tunica intima and tunica media of a carotid artery, called intima-media thickness (IMT), is a determinant of an advancement in an atherosclerotic process, and it also correlates with a total cardiovascular risk [10]. In the study of Arias-Santiago et al. men with an early onset of andro-

\section{WPROWADZENIE}

Łysienie androgenowe jest najczęstszą przyczyną nadmiernego wypadania włosów u osób dorosłych $[1,2]$. Poza negatywnym wpływem łysienia androgenowego na jakość życia [3] coraz więcej badań wskazuje na jego związek ze zwiększonym ryzykiem sercowo-naczyniowym $[4,5]$. U osób z łysieniem androgenowym częściej stwierdza się przyspieszony rozwój miażdżycy, nadciśnienie tętnicze, dyslipidemię, insulinooporność i otyłość.

\section{MIAŻDŻYCA}

Pierwsza informacja o związku łysienia androgenowego z chorobami serca została opublikowana przez Cottona i wsp. na łamach „British Heart Journal” w 1972 r. [6]. Prowadzone w kolejnych latach badania epidemiologiczne potwierdziły istnienie tego powiązania. Trwająca od 1948 r. analiza populacji miasta Framingham (Framingham Heart Study) wykazała związek między szybkością progresji i nasileniem łysienia androgenowego u mężczyzn a wystąpieniem choroby wieńcowej oraz zwiększonym ryzykiem zgonu z powodu zawału serca [7]. Christoffersen i wsp. przedstawili wyniki 35-letniej obserwacji 10885 kobiet i mężczyzn w ramach badania Copenhagen City Heart Study [8]. Autorzy potwierdzili, że łysienie androgenowe zwiększa ryzyko wystąpienia choroby niedokrwiennej serca $(1,4 \times)$ i zawału serca $(1,57 \times)$, niezależnie od płci oraz obecności innych czynników zdarzeń sercowo-naczyniowych [8]. Metaanaliza 31 badań przekrojowych, w których łącznej ocenie zostało poddanych 29254 pacjentów, wykazała, że łysienie androgenowe zwiększa ryzyko wystąpienia choroby wieńcowej $(1,22 \times)$, które ponadto dodatnio koreluje ze stopniem nasilenia łysienia [9].

$\mathrm{O}$ związku między łysieniem androgenowym a przyspieszonym rozwojem miażdżycy świadczą także pośrednie dowody pochodzące $\mathrm{z}$ badań obrazowych i laboratoryjnych. Ultrasonograficzna ocena grubości warstwy wewnętrznej i środkowej ściany tętnic szyjnych, określanej jako wskaźnik IMT (intima-media thickness), stanowi wyznacznik zaawansowania procesu miażdżycowego i dodatnio koreluje z całkowitym ryzykiem sercowo-naczyniowym [10]. W badaniu 
genetic alopecia were characterized by a significantly higher IMT value than people belonging to the control group [11]. Moreover, the presence of atherosclerotic plaques in carotid arteries was confirmed in $34 \%$ of the examined patients with androgenetic alopecia, whereas the percentage in the control ground amounted to 8.6\% [11]. Ertas et al. examined 51 men with androgenetic alopecia, which began before they turned 30, and described a significantly higher IMT values in patients with alopecia affecting the vertex of the scalp [12]. An analysis of Colgecen et al. showed a positive correlation between the IMT and androgenetic alopecia [13].

Plasma homocysteine and lipoprotein (a) - Lp(a) - concentrations are considered to be independent biochemical markers of an increased cardiovascular risk [14]. Sharma et al. confirmed a higher homocysteine concentration in men with androgenetic alopecia $(20.67 \pm 4.2 \mu \mathrm{mol} / \mathrm{ml})$ than in the control group (10.08 $\pm 1.9 \mu \mathrm{mol} / \mathrm{ml}$ ) [15]. Similarly, Lp(a) concentration was higher in patients with androgenetic alopecia (27.37 $\pm 6.1 \mathrm{mg} / \mathrm{dl}$ in the examined group, and 19.51 $\pm 4.0 \mathrm{mg} / \mathrm{dl}$ in the control group) [15]. Concentrations of both markers were increasing along with the severity of alopecia [15].

A hyperactivity of $5 \alpha$-reductase is considered to be responsible for damage of the endothelium and an accelerated development of atherosclerosis in patients with androgenetic alopecia. This enzyme is expressed not only in hair follicles, but also in heart and vascular walls [16]. The emerging dihydrotestosterone (DHT) causes a miniaturization of hair follicles [2], proliferation and hypertrophy of vascular smooth muscle cells [16].

\section{ARTERIAL HYPERTENSION}

Arterial hypertension is the most important cardiovascular risk factor that influences morbidity and mortality caused by cardiovascular diseases [17]. A number of observational studies proved a considerably more frequent occurrence of arterial hypertension in people with diagnosed androgenetic alopecia, regardless of their sex and age $[4,5]$. Men and women suffering from androgenetic alopecia are found to have higher values of mean arterial blood pressure as compared with the control group [11]. A meta-analysis including 7 studies and a total of 1,411 patients confirmed that in people with androgenetic alopecia the risk of increased values of systolic arterial pressure is 1.73 times higher, whereas in case of diastolic arterial pressure it is 1.59 times higher [9]. Triantafyllidi et al., who examined 101 patients with recently diagnosed arterial hypertension, presented interesting results [18]. The authors showed that patients with arterial hypertension and concurrent androgenetic alopecia with
Ariasa-Santiago i wsp. mężczyźni o wczesnym początku łysienia androgenowego mieli znacznie większe wartości wskaźnika IMT niż osoby z grupy kontrolnej [11]. Ponadto u pacjentów z łysieniem androgenowym obecność blaszki miażdżycowej w tętnicach szyjnych stwierdzono wśród 34\% badanych, podczas gdy odsetek ten w grupie kontrolnej wyniósł - 8,6\% [11]. Ertas i wsp. przebadali 51 mężczyzn z łysieniem androgenowym, które rozpoczęło się przed 30. rokiem życia, i stwierdzili znacznie większą wartość wskaźnika IMT u pacjentów z łysieniem w okolicy wierzchołkowej [12]. Analiza, którą przeprowadzili Colgecen i wsp., wykazała dodatnią korelację pomiędzy wskaźnikiem IMT a łysieniem androgenowym [13].

Stężenie homocysteiny oraz lipoproteiny (a) [Lp(a)] w osoczu uznano za niezależne biochemiczne markery zwiększonego ryzyka sercowo-naczyniowego [14]. Sharma i wsp. obserwowali większe stężenie homocysteiny u mężczyzn z łysieniem androgenowym $(20,67 \pm 4,2 \mu \mathrm{mol} / \mathrm{ml})$ w porównaniu z grupą kontrolną $(10,08 \pm 1,9 \mu \mathrm{mol} / \mathrm{ml})$ [15]. Podobnie stężenie $\mathrm{Lp}(\mathrm{a})$ było większe $\mathrm{u}$ pacjentów $\mathrm{z}$ łysieniem androgenowym $(27,37 \pm 6,1 \mathrm{mg} / \mathrm{dl} w$ grupie badanej i 19,51 $\pm 4,0 \mathrm{mg} / \mathrm{dl}$ w grupie kontrolnej) [15]. Stężenia obu markerów zwiększały się wraz ze stopniem nasilenia łysienia [15].

Za przyczynę uszkodzenia śródbłonka i przyspieszony rozwój miażdżycy u pacjentów z łysieniem androgenowym uznaje się nadaktywność $5 \alpha$-reduktazy. Enzym ten poza mieszkami włosowymi ulega ekspresji również w sercu i ścianie naczyń krwionośnych [16]. Powstający dwuhydrotestosteron (DHT) powoduje miniaturyzację mieszków włosowych [2], a w ścianie naczyń proliferację i przerost komórek warstwy mięśniowej [16].

\section{NADCIŚNIENIE TEZTNICZE}

Nadciśnienie tętnicze jest najważniejszym czynnikiem ryzyka sercowo-naczyniowego, który wpływa na zachorowalność i śmiertelność z powodu chorób układu krążenia [17]. W wielu badaniach obserwacyjnych udowodniono znacznie częstsze występowanie nadciśnienia tętniczego u osób z rozpoznanym łysieniem androgenowym, niezależnie od płci i wieku $[4,5]$. Wśród kobiet i mężczyzn z łysieniem androgenowym stwierdza się wyższe wartości średniego ciśnienia tętniczego w porównaniu z grupą kontrolną [11]. Metaanaliza obejmująca 7 badań i łącznie 1411 pacjentów potwierdziła, że u osób z łysieniem androgenowym ryzyko wystąpienia podwyższonej wartości skurczowego ciśnienia tętniczego jest 1,73 razy większe, a rozkurczowego ciśnienia tętniczego - 1,59 razy [9]. Interesujące wyniki przedstawili Triantafyllidi i wsp., którzy zbadali 101 pacjentów z nowo rozpoznanym nadciśnieniem tętniczym [18]. 
early onset and high intensity were characterized by a decreased value of coronary flow reserve, what is indicative of coronary microcirculation disorders and a higher IMT value, which correlated with a severity of atherosclerotic process [18]. Patients with androgenetic alopecia also show an intensified arterial stiffness reflected by an increase in pulse wave velocity (PWV) [12]. An increased PWV value is an independent cardiovascular risk factor and positively correlates with the risk of ischaemic heart disease development and an occurrence of stroke [19].

An increased blood aldosterone concentration may be responsible for a relationship between arterial hypertension and androgenetic alopecia. Aldosterone is a mineralocorticoid responsible for water and electrolyte metabolism. An excess of aldosterone plays an important role in cardiovascular diseases. An increased blood aldosterone concentration was found in women and men with androgenetic alopecia [20]. It partly accounts for efficacy of spironolactone in a therapy for androgenetic alopecia in women [1]. A relationship between hyperaldosteronism and alopecia is also confirmed by experimental studies. Transgenic mice with an overexpression of aldosterone receptor present hair cycle disorders, hair follicle damage and hair loss [21].

\section{DYSLIPIDEMIA}

Dyslipidemias belong to the most important modifiable cardiovascular risk factors. A disrupted plasma lipid profile is observed in a number of inflammatory dermatoses, e.g. psoriasis [22] or lichen planus [23]. A relationship between disorders in lipid metabolism and androgenetic alopecia was confirmed in two metaanalyses. Patients with androgenetic alopecia are found to have an increased concentration of total cholesterol, triglycerides, and cholesterol LDL fractions (low density lipoprotein) considerably more often than the general population [9, 24]. Simultaneously, these patients have a decreased concentration of cholesterol HDL fraction (high density lipoprotein), which physiologically shows anti-atherogenic qualities [9, 24].

Pro-atherosclerotic changes in lipid metabolism in people with androgenetic alopecia are considered reasons behind hormonal disorders, especially an increased sensitivity to androgens and insulin resistance [25]. An influence of proinflammatory cytokines cannot be rules out either [25].

\section{INSULIN RESISTANCE}

Insulin resistance is defined as a condition in which normal insulin concentration causes a weaker
Autorzy wykazali, że pacjenci z nadciśnieniem tętniczym i współwystępującym łysieniem androgenowym o wczesnym początku i dużym nasileniu charakteryzowali się zmniejszoną wartością rezerwy wieńcowej, co świadczy o zaburzeniach w mikrokrążeniu wieńcowym, oraz wyższą wartością wskaźnika IMT, który koreluje z nasileniem procesu miażdżycowego [18]. Wśród pacjentów z łysieniem androgenowym dochodzi do zwiększenia sztywności tętnic, którego odzwierciedleniem jest wzrost prędkości fali tętna (pulse wave velocity - PWV) [12]. Podwyższona wartość PWV jest niezależnym czynnikiem ryzyka sercowo-naczyniowego i dodatnio koreluje z ryzykiem rozwoju choroby wieńcowej i wystąpienia udaru mózgu [19].

Za związek nadciśnienia tętniczego z łysieniem androgenowym może odpowiadać zwiększone stężenie aldosteronu we krwi. Aldosteron należy do mineralokortykosteroidów, które odpowiadają za gospodarkę wodno-elektrolitową organizmu. Nadmiar aldosteronu odgrywa istotną rolę w chorobach układu sercowo-naczyniowego. Zwiększone stężenie aldosteronu we krwi stwierdzono u kobiet i mężczyzn z łysieniem androgenowym [20]. Częściowo tłumaczy to skuteczność spironolaktonu w terapii łysienia androgenowego $\mathrm{u}$ kobiet [1]. Związek pomiędzy hiperaldosteronizmem a łysieniem potwierdzają także badania eksperymentalne. U myszy transgenicznych z nadekspresją receptora dla aldosteronu dochodzi do zaburzenia cyklu włosowego, uszkodzenia mieszków włosowych i utraty owłosienia [21].

\section{DYSLIPIDEMIA}

Dyslipidemie należą do najważniejszych modyfikowalnych czynników ryzyka sercowo-naczyniowego. Zaburzony profil lipidów w osoczu obserwuje się w wielu dermatozach zapalnych, takich jak łuszczyca [22] i liszaj płaski [23]. Związek między zaburzeniami gospodarki lipidowej a łysieniem androgenowym potwierdzono w dwóch metaanalizach. U pacjentów z łysieniem androgenowym znacznie częściej niż w populacji ogólnej stwierdza się zwiększone stężenie cholesterolu całkowitego, trójglicerydów oraz frakcji LDL cholesterolu (lipoprotein o niskiej gęstości) $[9,24]$. Jednocześnie dochodzi u nich do zmniejszenia stężenia frakcji HDL cholesterolu (lipoprotein o wysokiej gęstości), który fizjologicznie ma właściwości antyaterogenne [9, 24].

Za przyczynę promiażdżycowych zmian w metabolizmie lipidów u osób z łysieniem androgenowym uznaje się zaburzenia hormonalne, zwłaszcza zwiększoną wrażliwość na androgeny oraz insulinooporność [25]. Nie można wykluczyć również wpływu cytokin o działaniu prozapalnym [25]. 
biological response in normal conditions. Hyperinsulinemia develops secondary to insulin resistance and plays an important role in development of cardiovascular complications. An increased insulin concentration conduces to atherogenesis by increasing cholesterol LDL fraction, triglyceride synthesis and proliferation of fibroblasts as well as vascular smooth muscle cells [26].

Prevalence of insulin resistance in patients with androgenetic alopecia is higher than in the general population matched with regard to sex and age [27, 28]. HOMA-IR (Homeostatic Model Assessment of Insulin Resistance) index score, calculated from a blood glucose and insulin concentration determined on an empty stomach, is higher in patients with androgenetic alopecia [27]. According to opinions of some researchers, androgenetic alopecia with an early onset may be considered as a marker of a developing insulin resistance.

The propounded relationship between insulin resistance and androgenetic alopecia probably results from a complex interaction of insulin with other hormones. Insulin resistance, and consequently, increased concentration of insulin-like growth factor (IGF), activates $5 \alpha$-reductase increasing DHT concentration [29]. In addition, by an increase in 17-hydroxylase activity, hyperinsulinemia increases androgen production in ovaries [30], what with a simultaneous inhibition of sex hormone binding globulin (SHBG) liver synthesis [31] causes an increased androgen bioavailability.

\section{OBESITY}

Adipose tissue is not only energy storage, but also a metabolically active endocrine organ. Thus, it is not surprising that visceral obesity is a significant risk factor for developing cardiovascular and metabolic diseases.

In observational studies men with androgenetic alopecia are characterized by a higher body mass index (BMI) value [32]. Yang et al. showed that patients with a greater severity of androgenetic alopecia (Hamilton-Norwood scale: V-VII) have higher BMI values $-25.1 \mathrm{~kg} / \mathrm{m}^{2}$ as compared with patients who have a lower severity of hair loss (Hamilton-Norwood scale: I-IV) $-22.8 \mathrm{~kg} / \mathrm{m}^{2}$ [33]. Androgenetic alopecia is associated with a more frequent occurrence of overweight and obesity in women, too [4].

Considering an influence on cardiovascular risk and hair loss, leptin is the most important adipokine secreted by adipose tissue. An increased leptin concentration was described in patients with obesity, ischaemic heart disease, and myocardial infarction [34]. A connection between leptin and cardiovascular events results from a stimulation of sympathetic

\section{INSULINOOPORNOŚĆ}

Insulinooporność definiuje się jako stan, w którym prawidłowe stężenie insuliny powoduje słabszą niż w warunkach prawidłowych odpowiedź biologiczną. Wtórnie do insulinooporności rozwija się hiperinsulinemia, która odgrywa istotną rolę w rozwoju powikłań sercowo-naczyniowych. Podwyższone stężenie insuliny sprzyja rozwojowi blaszki miażdżycowej przez zwiększenie frakcji LDL cholesterolu, syntezę trójglicerydów oraz proliferację fibroblastów i komórek mięśni gładkich ściany naczyń [26].

Częstość występowania insulinooporności u pacjentów z łysieniem androgenowym jest większa niż w populacji ogólnej dobranej pod względem płci i wieku [27, 28]. Wartość wskaźnika insulinooporności HOMA-IR, wyliczanego z oznaczonego na czczo stężenia glukozy i insuliny we krwi, jest wyższa u pacjentów z łysieniem androgenowym [27]. Według części badaczy łysienie androgenowe o wczesnym początku można uznać za marker rozwijającej się w organizmie insulinooporności.

Postulowany związek między insulinoopornością a łysieniem androgenowym wynika najprawdopodobniej ze złożonych interakcji insuliny z innymi hormonami. Insulinooporność i wynikające $z$ niej zwiększone stężenie insulinopodobnego czynnika wzrostu aktywuje $5 \alpha$-reduktazę, zwiększając stężenie DHT [29]. Dodatkowo hiperinsulinemia przez nasilenie aktywności 17-hydroksylazy zwiększa produkcję androgenów w jajnikach [30], co przy jednoczesnym zahamowaniu wątrobowej syntezy białka wiążącego hormony płciowe [31] powoduje zwiększoną biodostępność androgenów.

\section{OTYŁOŚĆ}

Tkanka tłuszczowa nie tylko stanowi rezerwuar energetyczny, lecz jest czynnym metabolicznie narządem wydzielania wewnętrznego. Nie dziwi więc fakt, że otyłość trzewna jest istotnym czynnikiem ryzyka rozwoju chorób sercowo-naczyniowych i metabolicznych.

W badaniach obserwacyjnych mężczyźni z łysieniem androgenowym charakteryzują się większą wartością wskaźnika masy ciała (body mass index BMI) [32]. Yang i wsp. wykazali, że pacjenci o większym nasileniu łysienia androgenowego (V-VII wg skali Hamiltona-Norwooda) mają większą wartość BMI - 25,1 kg/ $\mathrm{m}^{2}-\mathrm{w}$ porównaniu z pacjentami o mniejszym nasileniu utraty włosów (I-IV wg skali Hamiltona-Norwooda) - 22,8 kg/m² [33]. Również $\mathrm{u}$ kobiet łysienie androgenowe wiąże się z częstszym występowaniem nadwagi i otyłości [4].

Spośród adipokin uwalnianych przez tkankę tłuszczową szczególnie istotna pod względem wpły- 
nervous system, an acceleration of atherosclerotic plaque development, and an increase in blood platelet aggregation [34]. Leptin is also produced in skin, where it is responsible for regulating hair cycle and growth. Leptin, secreted from adipocytes of the subcutis, causes an inhibition of the anagen phase [35]. Yang et al. showed a higher leptin concentration in patients with androgenetic alopecia as compared with the control group matched according to age, sex, and BMI values [36]. Leptin concentration positively correlated with the severity of alopecia [36].

\section{METABOLIC SYNDROME}

The term metabolic syndrome refers to a co-occurrence of interrelated metabolic risk factors that can lead to development of atherosclerotic diseases. Metabolic syndrome includes: visceral obesity, insulin resistance, arterial hypertension, and lipid disorders. A co-occurrence of these components increases total cardiovascular risk to a more considerable extent than each and every component would separately.

Observational and cross-sectional studies confirm a more frequent prevalence of metabolic syndrome in women and men with androgenetic alopecia than in the general population. Criteria for diagnosing metabolic syndrome are met by $20-57 \%$ of patients with androgenetic alopecia [11,37].

An inflammation may be considered a common pathomechanism for the development of androgenetic alopecia and metabolic syndrome. Proinflammatory cytokines and immune system cells lead to the development of insulin resistance and damage of the vascular endothelium. Patients with androgenetic alopecia are found to have an inflammation around hair follicles [38]. This micro-inflammation may reflect a general inflammation in the body, which is responsible for increasing a cardiovascular risk. Serum of patients suffering from androgenetic alopecia with an early onset was found to have an increased concentration of oxidative stress markers [39].

\section{TREATMENT OF ANDROGENETIC ALOPECIA AND CARDIOVASCULAR RISK}

Results of studies regarding an influence of androgenetic alopecia on cardiovascular risk are ambiguous. $5 \alpha$-reductase inhibitors (finasteride and dutasteride) used in androgenetic alopecia act on enzyme isoforms located also outside hair follicles - in heart, vascular walls, and liver. Systemic effects of $5 \alpha$-reductase inhibitors include inhibition of cardiomyocyte hypertrophy [40], in- wu na ryzyko sercowo-naczyniowe i utratę włosów jest leptyna. Podwyższone stężenie leptyny opisano u pacjentów z otyłością, chorobą wieńcową i zawałem serca [34]. Związek leptyny z incydentami sercowo-naczyniowymi wynika z pobudzenia układu współczulnego, przyspieszenia rozwoju blaszki miażdżycowej oraz zwiększenia agregacji płytek krwi [34]. Leptyna produkowana jest również w skórze, gdzie odpowiada m.in. za regulację cyklu i wzrost włosa. Uwalniana $z$ adipocytów tkanki podskórnej leptyna powoduje zahamowanie fazy anagenu [35]. Yang i wsp. wykazali większe stężenie leptyny u pacjentów z łysieniem androgenowym w porównaniu z grupą kontrolną dobraną pod względem wieku, płci i BMI [36]. Stężenie leptyny dodatnio korelowało ze stopniem nasilenia łysienia [36].

\section{ZESPÓŁ METABOLICZNY}

Termin zespót metaboliczny określa współwystępowanie powiązanych ze sobą czynników ryzyka pochodzenia metabolicznego, sprzyjających rozwojowi chorób o podłożu miażdżycowym. Do zespołu metabolicznego zalicza się: otyłość trzewną, insulinooporność, nadciśnienie tętnicze i zaburzenia lipidowe. Współwystępowanie tych składowych zwiększa sumaryczne ryzyko sercowo-naczyniowe w znacznie większym stopniu, niż wynikałoby to z działania każdego $\mathrm{z}$ nich osobno.

Badania obserwacyjne i przekrojowe potwierdzają częstsze występowanie zespołu metabolicznego u kobiet i mężczyzn z łysieniem androgenowym niż w populacji ogólnej. Kryteria rozpoznania zespołu metabolicznego spełnia $20-57 \%$ pacjentów z łysieniem androgenowym [11, 37].

Za wspólny patomechanizm rozwoju łysienia androgenowego i zespołu metabolicznego można uznać stan zapalny. Prozapalne cytokiny i komórki układu odpornościowego prowadzą do rozwoju insulinooporności oraz uszkodzenia śródbłonka naczyń. U pacjentów z łysieniem androgenowym wokół mieszków włosowych stwierdza się odczyn zapalny [38]. To mikrozapalenie może być odzwierciedleniem ogólnego stanu zapalnego w organizmie, odpowiedzialnego za zwiększenie ryzyka sercowo-naczyniowego. W surowicy pacjentów z łysieniem androgenowym o wczesnym początku stwierdzono zwiększone stężenia markerów stresu oksydacyjnego [39].

\section{LECZENIE ŁYSIENIA ANDROGENOWEGO A RYZYKO SERCOWO-NACZYNIOWE}

Wyniki badań dotyczących wpływu terapii łysienia androgenowego na ryzyko sercowo-naczyniowe nie są jednoznaczne. Stosowane w łysieniu androge- 
hibition of abnormal angiogenesis [41], decrease in insulin-sensitivity, and increase in concentration of cholesterol LDL fraction [42]. These divergent results, considering the cardiovascular risk, may be associated with a complex influence of testosterone and its derivatives (DHT) on the circulatory system. Testosterone concentration that is higher than physiological has been proved to have a negative influence on cardiovascular risk; however, according to recent studies also a decrease in testosterone concentration may impair normal functioning of the circulatory system and metabolic processes [43]. According to conducted meta-analyses cardiovascular risk does not change during therapies with finasteride or dutasteride [44].

Spironolactone, used off-label in treating androgenetic alopecia in women, has been established in cardiological therapies for patients with myocardial insufficiency and resistant arterial hypertension for years [1].

Minoxidil, which was initially used as an oral hypotensive drug, has started to be applied topically in treatment of androgenetic alopecia in women and men [1]. Apart from dilating vessels and increasing flow of skin microcirculation, the drug shows anti-inflammatory properties [45]. New reports indicate a possibility to use oral form of the drug in therapies for androgenetic alopecia [46]. However, so far there have been no studies that would determine whether anti-inflammatory properties of minoxidil could decrease cardiovascular risk in systemic therapy.

Interestingly, according to recent studies, Mediterranean diet recommended in prevention of cardiological diseases decreases the risk of developing androgenetic alopecia [47].

\section{CONCLUSIONS}

Androgenetic alopecia, especially the one with an early onset, is connected to an increased cardiovascular risk in women and men. People with androgenetic alopecia were confirmed to suffer from a more frequent concurrent metabolic syndrome and its components (arterial hypertension, dyslipidemia, insulin resistance, and visceral obesity). Probable mechanisms responsible for cardiovascular risk in androgenetic alopecia are presented in figure 1. Despite the fact that treatment of androgenetic alopecia does not seem to influence the frequency of cardiovascular event occurrence in a considerable way, patients with this type of hair loss should be monitored periodically in order to identify other risk factors for the circulatory system, and introduce appropriate prophylaxis. nowym inhibitory $5 \alpha$-reduktazy (finasteryd i dutasteryd) działają na izoformy enzymu zlokalizowane również poza mieszkiem włosowym - w sercu, ścianie naczyń, wątrobie. Do ogólnoustrojowych efektów stosowania inhibitorów $5 \alpha$-reduktazy zalicza się: hamowanie przerostu kardiomiocytów [40], zablokowanie nieprawidłowej angiogenezy [41], zmniejszenie wrażliwości na insulinę i zwiększenie stężenia frakcji LDL cholesterolu [42]. Te rozbieżne pod względem ryzyka sercowo-naczyniowego wyniki mogą być związane ze złożonym wpływem testosteronu i jego pochodnych (DHT) na układ krążenia. Stężenie testosteronu przekraczające wartości fizjologiczne od dawna ma udowodniony niekorzystny wpływ na ryzyko sercowo-naczyniowe, ale według najnowszych badań również redukcja stężenia testosteronu może upośledzać funkcjonowanie układu krążenia i procesów metabolicznych [43]. Według przeprowadzonych metaanaliz całkowite ryzyko sercowo-naczyniowe nie zmienia się podczas terapii finasterydem lub dutasterydem [44].

Spironolakton stosowany poza wskazaniami rejestracyjnymi w łysieniu androgenowym $u$ kobiet od lat ma ugruntowaną pozycję $\mathrm{w}$ terapii kardiologicznej u pacjentów z niewydolnością serca i opornym nadciśnieniem tętniczym [1].

Minoksydyl, początkowo stosowany doustnie jako lek hipotensyjny, w formie miejscowej znalazł zastosowanie w leczeniu łysienia androgenowego u kobiet i mężczyzn [1]. Poza rozszerzaniem naczyń i zwiększaniem przepływu w mikrokrążeniu skórnym, lek ma właściwości przeciwzapalne [45]. Nowe doniesienia wskazują na możliwość zastosowania doustnej postaci minoksydylu w terapii łysienia androgenowego [46]. Brakuje jeszcze badań, które określiłyby, czy przeciwzapalne właściwości minoksydylu w czasie terapii systemowej mogą zmniejszyć ryzyko sercowo-naczyniowe.

Co ciekawe, zalecana w profilaktyce chorób kardiologicznych dieta śródziemnomorska według najnowszych badań zmniejsza ryzyko rozwoju łysienia androgenowego [47].

\section{PODSUMOWANIE}

Łysienie androgenowe, zwłaszcza o wczesnym początku, wiąże się ze zwiększonym ryzykiem sercowo-naczyniowym u kobiet i mężczyzn. U osób z łysieniem androgenowym potwierdzono częstsze współwystępowanie zespołu metabolicznego i jego poszczególnych składowych (nadciśnienia tętniczego, dyslipidemii, insulinooporności, otyłości trzewnej). Prawdopodobne mechanizmy odpowiedzialne za wzrost ryzyka sercowo-naczyniowego w łysieniu androgenowym przedstawiono na rycinie 1 . Mimo że wydaje się, że leczenie łysienia androgenowego nie 


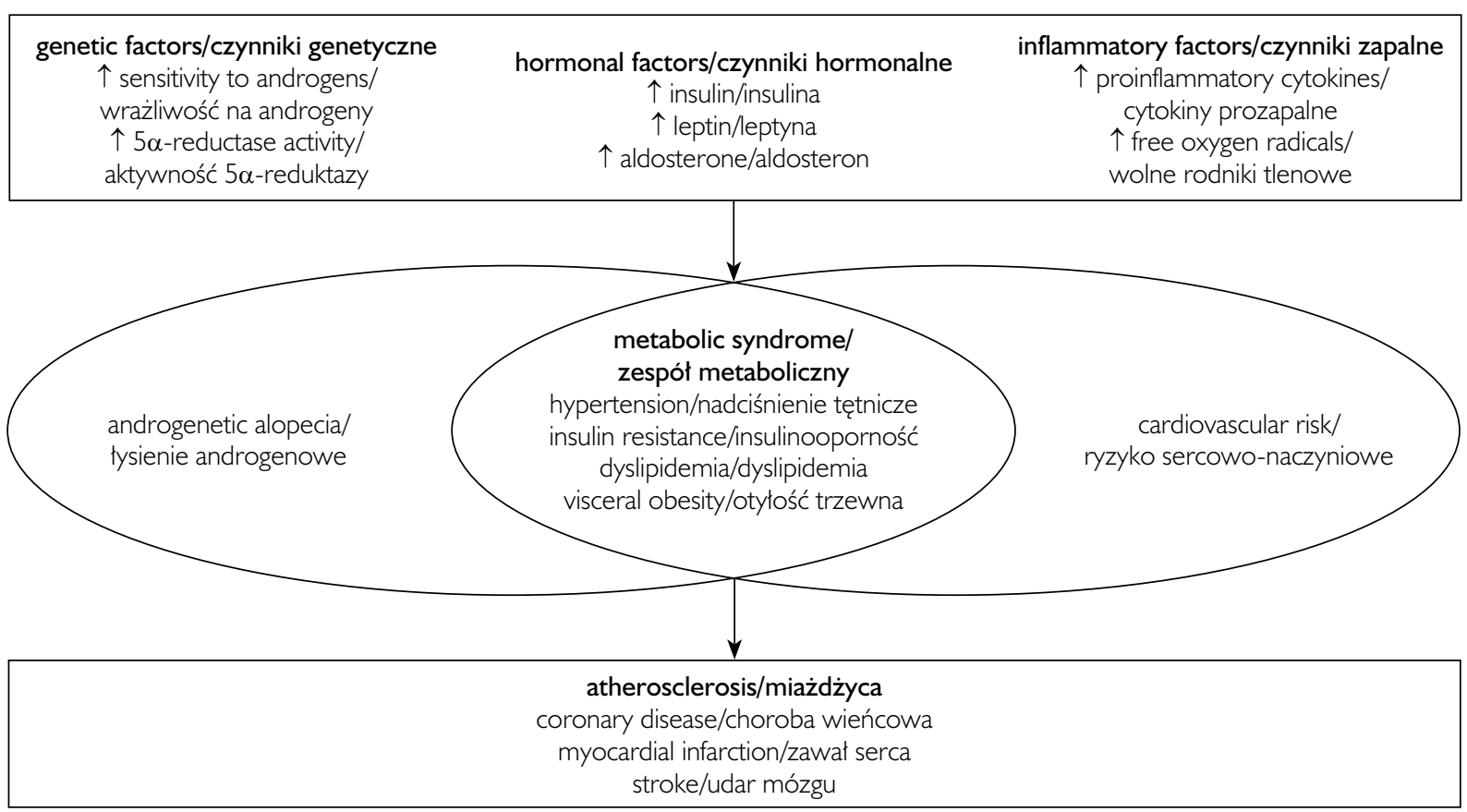

Figure I. Pathophysiology of increased cardiovascular risk in androgenetic alopecia

Rycina I. Patofizjologia zwiększonego ryzyka sercowo-naczyniowego w tysieniu androgenowym

\section{CONFLICT OF INTEREST}

The authors declare no conflict of interest. wpływa istotnie na częstość występowania incydentów sercowo-naczyniowych, to pacjenci z tym typem utraty włosów powinni być okresowo monitorowani w celu identyfikacji innych czynników ryzyka wystąpienia chorób układu krążenia oraz wdrożenia odpowiednich działań profilaktycznych.

\section{KONFLIKT INTERESOW}

Autorzy nie zgłaszają konfliktu interesów.

\section{References}

\section{Piśmiennictwo}

1. Brzezińska-Wcisło L., Rakowska A., Rudnicka L., Bergler-Czop B., Czuwara J., Maj J., et al.: Łysienie androgenowe kobiet i mężczyzn. Rekomendacje diagnostyczno-terapeutyczne Polskiego Towarzystwa Dermatologicznego. Dermatol Rev/Przegl Dermatol 2018, 105, 1-18.

2. Lis-Święty A.: Łysienie androgenetyczne. [in]: Choroby włosów i skóry owłosionej. Brzezińska-Wcisło (ed.) Termedia, Poznań, 2015, 125-154.

3. Jun M., Keum D.I., Lee S., Kim B.J., Lee W.S.: Quality of life with alopecia areata versus androgenetic alopecia assessed using Hair Specific Skindex-29. Ann Dermatol 2018, 30, 388-391.

4. Kim B.K., Choe S.J., Chung H.C., Oh S.S., Lee W.S.: Gender-specific risk factors for androgenetic alopecia in the Korean general population: associations with medical comorbidities and general health behaviors. Int J Dermatol 2018, 57, 183-192.

5. Park S.Y., Oh S.S., Lee W.S.: Relationship between androgenetic alopecia and cardiovascular risk factors according to BASP classification in Koreans. J Dermatol 2016, 43, 1293-1300.

6. Cotton S.G., Nixon J.M., Carpenter R.G., Evans D.W.: Factors discriminating men with coronary heart disease from healthy controls. Br Heart J 1972, 34, 458-464.

7. Herrera C.R., D'Agostino R.B., Gerstman B.B., Bosco L.A., Belanger A.J.: Baldness and coronary heart disease rates in men from the Framingham Study. Am J Epidemiol 1995, 142, 828-833.

8. Christoffersen M., Frikke-Schmidt R., Schnohr P., Jensen G.B., Nordestgaard B.G., Tybjaerg-Hansen A.: Visible age-related signs and risk of ischemic heart disease in the general population: a prospective cohort study. Circulation 2014, 129, 990-998.

9. Trieu N., Eslick G.D.: Alopecia and its association with coronary heart disease and cardiovascular risk factors: a meta-analysis. Int J Cardiol 2014, 176, 687-695. 
10. Zaid M., Fujiyoshi A., Kadota A., Abbott R.D., Miura K.: Coronary artery calcium and carotid artery intima media thickness and plaque: clinical use in need of clarification. J Atheroscler Thromb 2017, 24, 227-239.

11. Arias-Santiago S., Gutierrez-Salmeron M.T., Castellote-Caballero L., Buendia-Eisman A., Naranjo-Sintes R.: Male androgenetic alopecia and cardiovascular risk factors: a case-control study. Actas Dermosifiliogr 2010, 101, $248-256$.

12. Ertas R., Orscelik O., Kartal D., Dogan A., Ertas S.K., Aydogdu E.G., et al.: Androgenetic alopecia as an indicator of metabolic syndrome and cardiovascular risk. Blood Press 2016, 25, 141-148.

13. Colgecen E., Ede H., Erkoc M.F., Akyuz Y., Erbay A.R.: The relation of androgenetic alopecia severity with epicardial fat thickness. Ann Dermatol 2016, 28, 205-209.

14. Lacey B., Herrington W.G., Preiss D., Lewington S., Armitage J.: The role of emerging risk factors in cardiovascular outcomes. Curr Atheroscler Rep 2017, 19, 28.

15. Sharma L., Dubey A., Gupta P.R., Agrawal A.: Androgenetic alopecia and risk of coronary artery disease. Indian Dermatol Online J 2013, 4, 283-287.

16. Fujimoto R., Morimoto I., Morita E., Sugimoto H., Ito Y., Eto S.: Androgen receptors, 5 alpha-reductase activity and androgen-dependent proliferation of vascular smooth muscle cells. J Steroid Biochem Mol Biol 1994, 50, $169-174$.

17. Kjeldsen S.E.: Hypertension and cardiovascular risk: general aspects. Pharmacol Res 2018, 129, 95-99.

18. Triantafyllidi H., Grafakos A., Ikonomidis I., Pavlidis G., Trivilou P., Schoinas A., et al.: Severity of alopecia predicts coronary changes and arterial stiffness in untreated hypertensive men. J Clin Hypertens (Greenwich) 2017, 19, 51-57.

19. Ben-Shlomo Y., Spears M., Boustred C., May M., Anderson S.G., Benjamin E.J., et al.: Aortic pulse wave velocity improves cardiovascular event prediction: an individual participant meta-analysis of prospective observational data from 17,635 subjects. J Am Coll Cardiol 2014, 63, 636-646.

20. Arias-Santiago S., Gutierrez-Salmeron M.T., Castellote-Caballero L., Naranjo-Sintes R.: Elevated aldosterone levels in patients with androgenetic alopecia. Br J Dermatol 2009, 161, 1196-1198.

21. Sainte Marie Y., Toulon A., Paus R., Maubec E., Cherfa A., Grossin M., et al.: Targeted skin overexpression of the mineralocorticoid receptor in mice causes epidermal atrophy, premature skin barrier formation, eye abnormalities, and alopecia. Am J Pathol 2007, 171, 846-860.

22. Coban M., Tasli L., Turgut S., Ozkan S., Tunc Ata M., Akin F.: Association of adipokines, insulin resistance, hypertension and dyslipidemia in patients with psoriasis vulgaris. Ann Dermatol 2016, 28, 74-79.

23. Lai Y.C., Yew Y.W., Schwartz R.A.: Lichen planus and dyslipidemia: a systematic review and meta-analysis of observational studies. Int J Dermatol 2016, 55, e295-304.

24. Kim M.W., Shin I.S., Yoon H.S., Cho S., Park H.S.: Lipid profile in patients with androgenetic alopecia: a meta-analysis. J Eur Acad Dermatol Venereol 2017, 31, 942-951.

25. Kolovou G.D., Anagnostopoulou K.K., Cokkinos D.V.: Pathophysiology of dyslipidaemia in the metabolic syndrome. Postgrad Med J 2005, 81, 358-366.

26. Dongerkery S.P., Schroeder P.R., Shomali M.E.: Insulin and its cardiovascular effects: what is the current evidence? Curr Diab Rep 2017, 17, 120.

27. Cannarella R., La Vignera S., Condorelli R.A., Calogero A.E.: Glycolipid and hormonal profiles in young men with earlyonset androgenetic alopecia: a meta-analysis. Sci Rep 2017, 7, 7801.

28. Kartal D., Borlu M., Cinar S.L., Ferahbas A., Ulas Y., Unluhizarci K., et al.: The association of androgenetic alopecia and insulin resistance is independent of hyperandrogenemia: a case-control study. Australas J Dermatol 2016, 57, e88-92.

29. Kayampilly P.P., Wanamaker B.L., Stewart J.A., Wagner C.L., Menon K.M.: Stimulatory effect of insulin on 5alpha-reductase type 1 (SRD5A1) expression through an Akt-dependent pathway in ovarian granulosa cells. Endocrinology 2010, 151, 50305037.

30. Munir I., Yen H.W., Geller D.H., Torbati D., Bierden R.M., Weitsman S.R., et al.: Insulin augmentation of 17alpha-hydroxylase activity is mediated by phosphatidyl inositol 3-kinase but not extracellular signal-regulated kinase-1/2 in human ovarian theca cells. Endocrinology 2004, 145, 175-183.

31. Haffner S.M.: Sex hormone-binding protein, hyperinsulinemia, insulin resistance and noninsulin-dependent diabetes. Horm Res 1996, 45, 233-237.

32. Ozturk P., Kurutas E., Ataseven A., Dokur N., Gumusalan Y., Gorur A., et al.: BMI and levels of zinc, copper in hair, serum and urine of Turkish male patients with androgenetic alopecia. J Trace Elem Med Biol 2014, 28, $266-270$.

33. Yang C.C., Hsieh F.N., Lin L.Y., Hsu C.K., Sheu H.M., Chen W.: Higher body mass index is associated with greater severity of alopecia in men with male-pattern androgenetic alopecia in Taiwan: a cross-sectional study. J Am Acad Dermatol 2014, 70, 297-302 e291.

34. Katsiki N., Mikhailidis D.P., Banach M.: Leptin, cardiovascular diseases and type 2 diabetes mellitus. Acta Pharmacol Sin 2018, 39, 1176-1188.

35. Yang C.C., Sheu H.M., Chung P.L., Chang C.H., Tsai Y.S., Hughes M.W., et al.: Leptin of dermal adipose tissue is differentially expressed during the hair cycle and contributes to adipocyte-mediated growth inhibition of anagen-phase vibrissa hair. Exp Dermatol 2015, 24, 57-60.

36. Yang C.C., Chung P.L., Lin L.Y., Hughes M.W., Tsai Y.S.: Higher plasma leptin is associated with higher risk of androgenetic alopecia in men. Exp Dermatol 2017, 26, 524-526.

37. Lie C., Liew C.F., Oon H.H.: Alopecia and the metabolic syndrome. Clin Dermatol 2018, 36, 54-61.

38. El-Domyati M., Attia S., Saleh F., Abdel-Wahab H.: Androgenetic alopecia in males: a histopathological and ultrastructural study. J Cosmet Dermatol 2009, 8, 83-91.

39. Kaya Erdogan H., Bulur I., Kocaturk E., Yildiz B., Saracoglu Z.N., Alatas O.: The role of oxidative stress in early-onset androgenetic alopecia. J Cosmet Dermatol 2017, 16, 527-530.

40. Zwadlo C., Schmidtmann E., Szaroszyk M., Kattih B., Froese N., Hinz H., et al.: Antiandrogenic therapy with finasteride attenuates cardiac hypertrophy and left ventricular dysfunction. Circulation 2015, 131, 1071-1081. 
41. Tian H.L., Zhao C.X., Wu H.Y., Xu Z.X., Wei L.S., Zhao R.T., et al.: Finasteride reduces microvessel density and expression of vascular endothelial growth factor in renal tissue of diabetic rats. Am J Med Sci 2015, 349, 516-520.

42. Traish A.M.: Negative impact of testosterone deficiency and 5alpha-reductase inhibitors therapy on metabolic and sexual function in men. Adv Exp Med Biol 2017, 1043, 473-526.

43. Elagizi A., Kohler T.S., Lavie C.J.: Testosterone and cardiovascular health. Mayo Clin Proc 2018, 93, 83-100.

44. Skeldon S.C., Macdonald E.M., Law M.R., Huang A., Paterson J.M., Mamdani M.M., et al.: The cardiovascular safety of dutasteride. J Urol 2017, 197, 1309-1314.

45. Pekmezci E., Turkoglu M., Gokalp H., Kutlubay Z.: Minoxidil downregulates interleukin-1 alpha gene expression in HaCaT cells. Int J Trichology 2018, 10, 108-112.

46. Sinclair R.D.: Female pattern hair loss: a pilot study investigating combination therapy with low-dose oral minoxidil and spironolactone. Int J Dermatol 2018, 57, 104-109.

47. Fortes C., Mastroeni S., Mannooranparampil T., Abeni D., Panebianco A.: Mediterranean diet: fresh herbs and fresh vegetables decrease the risk of androgenetic alopecia in males. Arch Dermatol Res 2018, 310, 71-76.

Received: 20.02 .2018

Accepted: 5.11 .2018

Otrzymano: 20.02.2018 r

Zaakceptowano: $5.11 .2018 \mathrm{r}$. 